\title{
Improvements of luciferin-luciferase methodology for determi- nation of adenylate energy charge ratio of marine samples
}

\author{
Jette Klinken* and Hein R. Skjoldal** \\ Institute of Marine Biology, University of Bergen, Blomsterdalen, Norway
}

ABSTRACT: Application of adenylate energy charge (EC) measurements in marine ecological studies requires high accuracy and precision. We have examined the luciferinluciferase method for EC determination and suggest the following methodological improvements. Replacement of the commonly used potassium phosphate buffer with potassium chloride in the assay medium prevents problems due to precipitation of magnesium phosphates. Interference from ADP and AMP in crude firefly extract can be eliminated by their enzymatic decomposition with apyrase and AMP-deaminase. Impure nucleotide standards are perhaps more common than currently realized, and can lead to inaccurate estimates of EC.

The adenylate energy charge ratio $(\mathrm{EC}=[\mathrm{ATP}+1 / 2$ $\mathrm{ADP}] /[\mathrm{ATP}+\mathrm{ADP}+\mathrm{AMP}]$; Atkinson, 1977) has been proposed as an index of the energetical state of natural microbial communities and applied to both water and sediment samples (e. g. Wiebe and Bancroft, 1975; Witzel, 1979; Christensen and Devol, 1980; Karl, 1980; Románo and Daumas, 1981). EC measurements have also been used in studies of various types of stress in marine invertebrates (Ivanovici, 1980; Haya and Waiwood, in press). The EC ratio is normally stabilized at about 0.9 and changes in EC associated with environmental and physiological changes are usually small (Atkinson, 1977; Karl, 1980). High accuracy and precision in measurements are therefore important requirements for future evaluations of the usefulness of the EC ratio for ecological applications. We have examined the luciferin-luciferase methodology for EC determination with regard to potential interferences and standardization requirements.

Fifty $\mathrm{mg}$ freeze-dried firefly lantern extract (FLE-50; Sigma) were rehydrated with 10 to $25 \mathrm{ml}$ distilled water and aged successively for 4 and 12 to $48 \mathrm{~h}$ at room temperature and refrigerated, respectively. The

\footnotetext{
- Present address: Bustrupgade $6^{\mathrm{IVth}}, \mathrm{DK}-1737$, København V., Denmark

- Present address: Institute of Marine Research, Directorate of Fisheries, P.O. Box 1870, N-5011, Bergen-Nordnes, Norway

FLE preparation was cleared by centrifugation and warmed to room temperature prior to use. Enzymatic treatment of this FLE was performed by incubating a $5 \mathrm{ml}$ subsample with additions of $250 \mu \mathrm{l}$ AMP-deaminase (Sigma, Grade IV) and $0.5 \mathrm{mg}$ apyrase (ATP- and ADPase; Sigma, Grade I) for $4 \mathrm{~h}$ at room temperature. Adenine nucleotides (AN) in the FLE preparations were extracted by injecting $0.5 \mathrm{ml}$ FLE into $4.5 \mathrm{ml}$ boiling Tris-buffer/EDTA (Lundin and Thore, 1975).

ATP was assayed as described by Skjoldal and Barkati (1982). AMP and/or ADP were phosphorylated to ATP prior to assay by incubating $\left(30^{\circ} \mathrm{C}, 30 \mathrm{~min}\right) \mathrm{sam}-$ ple portions with phospho(enol)pyruvate (PEP), adenylate kinase (AK) and/or pyruvate kinase (PK) (Pradet, 1967). Two different sets of incubation reagents, based on either potassium phosphate $\left(\mathrm{KP}_{\mathrm{i}}\right)$ buffer or potassium chloride $(\mathrm{KCl})$, were compared in one experiment. In all other experiments the $\mathrm{KCl}$-reagents were used. The $\mathrm{KP}_{1}$ incubation method followed with slight modifications that of Chapman et al. (1971). To $250 \mu \mathrm{l}$ subsamples were added $50 \mu \mathrm{l} \mathrm{MgCl}_{2}$ (25 mM) and $50 \mu l$ reagent. The reagent for determination of ATP (ATP-reagent) was $\mathrm{KP}_{1}$-buffer $\left(\mathrm{K}_{2} \mathrm{HPO}_{4} / \mathrm{KH}_{2} \mathrm{PO}_{4}\right.$, $75 \mathrm{mM}, \mathrm{pH}$ 7.5). The reagent for determination of ATP $+\mathrm{ADP}$ (ADP-reagent) contained $\mathrm{KP}_{1}$-buffer, PEP $(0.45$ $\mathrm{mM}$; Sigma, tricyclohexylamine salt) and $10 \mu \mathrm{l}$ PKsuspension (Sigma, Type II) per ml. The reagent for determination of ATP + ADP + AMP (AMP-reagent) contained $\mathrm{KP}_{\mathrm{i}}$-buffer, PEP, PK, and $10 \mu \mathrm{AK}$-suspension (Sigma, Grade III) per $\mathrm{ml}$. In the incubation method based on $\mathrm{KCl}, 50 \mu \mathrm{l}$ reagent was added to $250 \mu \mathrm{l}$ subsamples. The ATP-reagent consisted of $\mathrm{MgCl}_{2}(25 \mathrm{mM}), \mathrm{KCl}(8 \mathrm{mM})$, and PEP $(0.75 \mathrm{mM})$. The ADP-reagent contained 5 or $10 \mu \mathrm{l}$ PK-suspension per ml ATP-reagent. The AMP-reagent contained $10 \mu \mathrm{l}$ AK-suspension per ml ADP-reagent. Following incubation, samples were kept on ice until assayed for ATP the same day. 
Stock AN standard solutions of about $30 \mu \mathrm{M}$ concentration were prepared using sodium salt of AMP and dibarium salts of ATP and ADP (Sigma). AMP was dissolved in Tris-buffer $(0.02 \mathrm{M}, \mathrm{pH} 7.7)$ and ATP and ADP were dissolved in Tris-buffer containing $\mathrm{Na}_{2} \mathrm{SO}_{a}$ $(0.1 \mathrm{M})$. The precipitate of $\mathrm{BaSO}_{4}$ was removed by centrifugation and the supernatant further diluted with Tris-buffer. The exact concentrations of these standard stock solutions were determined spectrophotometrically at $260 \mathrm{~nm}$. They were stored frozen in small portions, thawed and diluted with Tris-buffer as required prior to use.

The enzymes PK and AK are usually obtained as suspensions in 2 to $3 \mathrm{M}$ ammonium sulphate solution. Since inorganic salts inhibit the luciferase activity (e.g. Aledort et al., 1966; Karl and LaRock, 1975), many workers have either dialyzed the AK suspension against phosphate buffer (Chapman et al., 1971; Wit$z e l, 1979$ ) or centrifuged the PK and AK suspensions and resuspended the pellets in buffer (Lundin and Thore, 1975; Christensen and Devol, 1980; Romano and Daumas, 1981). We have instead used untreated enzyme suspensions and corrected the light-emission values for the inhibition caused by $\left(\mathrm{NH}_{4}\right)_{2} \mathrm{SO}_{4}$. In our assay procedures, the concentrations of $\left(\mathrm{NH}_{4}\right)_{2} \mathrm{SO}_{4}$ in the incubation mixtures for determination of ATP, ATP $+\mathrm{ADP}$, and ATP + ADP + AMP were 0, 1.8 to 3.7, and 7.1 to $9.0 \mathrm{mM}$, respectively. These concentrations inhibited the luciferase activity by 2 to $4 \%$ and about $10 \%$ in the cases of ATP + ADP and ATP + ADP + AMP determinations, respectively.

Proteins such as hemoglobin and bovine serum albumin (BSA) have been reported to stimulate the luciferase activity (e.g. Beutler and Mathai, 1967). Thus, we found that $90 \mu \mathrm{g} \mathrm{BSA} \mathrm{ml}^{-1}$ stimulated the peak light emission by $14 \%$. The enzymes $P K$ and $A K$, on the other hand, had no detectable effects at concentrations up to $100 \mu \mathrm{g} \mathrm{ml}^{-1}$. Nor did we detect any effect of PEP at concentrations up to $0.9 \mathrm{mM}$. These concentrations cover the ranges of commonly used concentrations of $\mathrm{PK}, \mathrm{AK}$, and PEP.
Proper enzymatic conversion of ADP and AMP to ATP by $P K$ and $A K$ requires mono- and bivalent cations. $\mathrm{K}^{+}$and $\mathrm{Mg}^{++}$are most effective for $\mathrm{PK}$ (Kayne, 1973) and AK (Noda, 1973), respectively, and have therefore usually been included in incubation mixtures, although as different salts and at different concentrations. Assay modifications can on this basis be broadly classified into 3 categories: (1) those following the original assay of Pradet (1967) using the sulphate salts of $\mathrm{Mg}^{++}$and $\mathrm{K}^{+}$; (2) those following the assay of Chapman et al. (1971) using $\mathrm{MgCl}_{2}$ and $\mathrm{K}$ phosphates; and (3) those using $\mathrm{MgCl}_{2}$ and $\mathrm{KCl}$ (e. g. Kimmich et al. 1975). It has been argued that chloride salts should be avoided because of the inhibitory effect of $\mathrm{Cl}^{-}$on the luciferase activity (Pradet, 1967; Romano and Daumas, 1981). However, $\mathrm{Cl}^{-}$is reported as less inhibitory than equimolar concentrations of sulphate or phosphate (Aledort et al., 1966; Karl and LaRock, 1975).

We compared 2 assay modifications based respectively on $\mathrm{KP}_{\mathrm{i}}$ - and $\mathrm{KCl}$-reagents (Table 1). Light emission in the assay of ATP was about $20 \%$ lower with the $\mathrm{KP}_{\mathrm{i}}$ - than with the $\mathrm{KCl}$-reagent, probably reflecting the higher ionic strength of the former. When a $2 \mu \mathrm{M}$ ATP standard was analyzed by the $\mathrm{KP}_{j}$-method, the peak light emission was about equal with ATP- and ADPreagents, but $10 \%$ lower with AMP-reagent. With the $\mathrm{KCl}$-method, on the other hand, the light emission was 26 and $34 \%$ higher with the ADP- and AMP-reagents, respectively, than with the ATP-reagent (Table 1). Since we found no effect of either PEP, PK, or AK on the luciferase activity, we interpret this increased light emission with ADP- and AMP-reagents as reflecting contamination by ADP and AMP of the ATP standard. Analyses of ADP and AMP standards also indicated impurities, particularly of AMP in the ADP standard (Table 1). From these analyses we calculated that our ATP standard contained $19 \%$ ADP and $6 \%$ AMP, our ADP standard $16 \%$ AMP, and our AMP standard $0.1 \%$ ATP and $0.4 \%$ ADP. Although high, these contaminations are not exceptional compared to other reported

Table 1. Peak light emission (relative units) from standard solutions incubated with ATP-, ADP-and AMP-reagents of the KP $\mathrm{j}^{-}$or $\mathrm{KCl}$-method. Light emission values (mean [standard deviation] of 6 replicates) corrected for difference in incubation volume of the 2 methods and for $\left(\mathrm{NH}_{4}\right)_{2} \mathrm{SO}_{4}$-inhibition

\begin{tabular}{|lcrrrrc|}
\hline Standard & Method & ATP-reagent & ADP-reagent & AMP-reagent & $\begin{array}{c}\text { Observed/expected (\%) } \\
\text { ADP- } \\
\text { AMP- } \\
\text { reagent } \\
\text { reagent }\end{array}$ \\
\hline ATP, $2.02 \mu \mathrm{M}$ & $\mathrm{KP}_{\mathrm{i}}$ & $24.01(1.10)$ & $24.73(0.88)$ & $21.51(0.52)$ & 86.6 & 71.7 \\
& $\mathrm{KCl}$ & $30.76(1.12)$ & $38.82(1.72)$ & $41.17(2.26)$ & 100 & 100 \\
$\mathrm{ATP}+\mathrm{ADP}+\mathrm{AMP}$ & $\mathrm{KP}$ & $8.54(0.45)$ & $16.73(0.42)$ & $24.33(1.00)$ & 81.3 & 70.7 \\
$0.68 \mu \mathrm{M}$ of each & $\mathrm{KCl}$ & $10.06(0.20)$ & $23.22(0.74)$ & $39.51(1.95)$ & 95.8 & 97.5 \\
$\mathrm{ADP}, 2.08 \mu \mathrm{M}$ & $\mathrm{KCl}$ & $0.00-$ & $34.51(1.27)$ & $40.90(1.37)$ & - & - \\
$\mathrm{AMP}, 2.01 \mu \mathrm{M}$ & $\mathrm{KCl}$ & $0.03(0.00)$ & $0.20(0.01)$ & $38.76(1.40)$ & - & - \\
\hline
\end{tabular}


impurity levels of ATP and ADP standards (Holmsen et al., 1966, 1972; Kimmich et al., 1975).

Taking the impurities of our standards into account, the light emissions with ADP- and AMP-reagents were expressed as percentages of those expected from the assays with ATP-reagent, assuming complete conversion (Table 1). There was close to $100 \%$ agreement between observed and expected light emission when a mixture of ATP, ADP, and AMP were analyzed with the $\mathrm{KCl}$-method. In contrast, the light emission was inhibited by 15 to $19 \%$ and 28 to $29 \%$ with the ADPand AMP-reagents, respectively, of the $\mathrm{KP}_{\mathrm{i}}$-method.

The reason for this inhibition in the $\mathrm{KP}_{\mathrm{i}}$-method is probably related to precipitation of magnesium phosphates which have very low solubility in water. Upon mixing $\mathrm{KP}_{\mathrm{i}}$-buffer and $\mathrm{MgCl}_{2}$ we have always observed formation of a precipitate. Following incubation, the amount of precipitate increased in the order ATP-, ADP-, and AMP-reagent, reflecting perhaps precipitation of magnesium-ammonium phosphate. With $\mathrm{KCl}$-reagents, on the other hand, there was no visible precipitate formation. Since the degree of inhibition was quite similar in the analysis of either ATP or a mixture of all three AN (Table 1), the effect of lowered $\mathrm{Mg}^{++}$concentration was probably on the luciferase activity and not on the conversion enzymes PK and AK. The inhibitory effect would presumably depend on the $\mathrm{Mg}^{++}$concentration of the luciferase preparation, which in our case was 4 to $10 \mathrm{mM}$. The optimum $\mathrm{Mg}^{++}$ concentration for luciferase activity is in the range 1 to $10 \mathrm{mM}$, being dependent on ATP concentration and concentration of chelating agents such as EDTA which is often present in extraction media (Green and McElroy, 1956; Van Dyke et al., 1969; Karl and LaRock, 1975).

Proportionally lower light emission with ADP- and AMP-reagents as compared to ATP-reagent has previously been reported (e.g. Kimmich et al., 1975; Karl and Holm-Hansen, 1978; Witzel, 1979; Christensen and Devol, 1980; Skjoldal, 1981). Since different assay modifications were used, the reason for the lowered light emission may differ among the reports. Karl and Holm-Hansen (1978) found similar light emission with ATP- and ADP-reagents, but $15 \%$ lower with AMPreagent. The samples were boiled for $2 \mathrm{~min}$ following incubation in order to denature PK, and the lower light emission with AMP-reagent was explained as a result of an AK-catalyzed backproduction of ADP from ATP. Christensen and Devol (1980), following the same procedure, found light reduction also with ADP-reagent, which they ascribed to turbidity from coagulation of the PK after boiling.

To our knowledge, there are no previous reports of interference due to precipitation of $\mathrm{Mg}$ when $\mathrm{KP}_{1}$ and $\mathrm{MgCl}_{2}$ are used in the incubation mixtures. One reason for this could be commonly occurring ADP- and AMPcontaminations of ATP-standards, which would tend to counteract any such inhibitory effect (Table 1). We recommend that use of $\mathrm{KP}_{\mathrm{i}}$ in the incubation mixtures should be avoided, and that the purity of AN standards should be carefully checked. The method based on $\mathrm{KCl}$ instead of $\mathrm{KP}_{1}$ has proved satisfactory and yielded complete recovery of internal AN standards with both Tris-buffer and trichloroacetic acid extracts of various invertebrates (Skjoldal and Barkati, 1982; Klinken and Skjoldal, unpubl.).

Heat-treatment after incubation was introduced by Karl and Holm-Hansen (1978) in order to reduce interference in the luciferase assay due to conversion to ATP of nucleotides in crude FLE preparations. This interference, which has been discussed in several papers (e.g. Karl and Holm-Hansen 1978; Witzel, 1979; Romano and Daumas, 1981) is most severe with AMPreagent and at low ATP concentrations (Fig. $1 A_{1}$ to $C_{1}$ ). The heat-treatment results in back production of ADP from ATP, and there is also a possibility of other losses of ATP during the heating and reequilibration periods

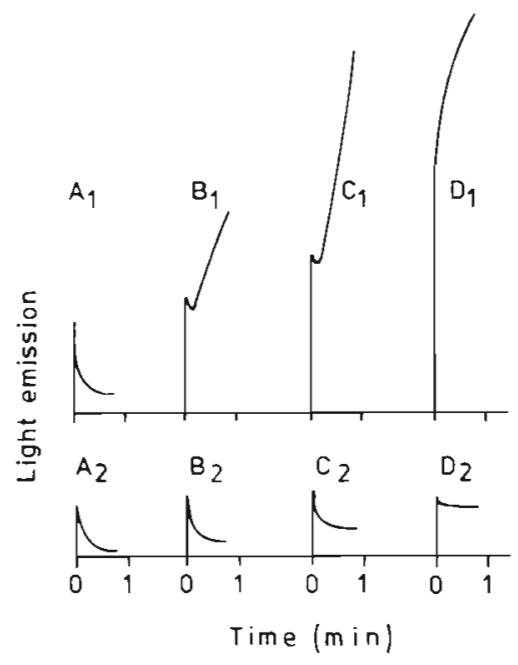

Fig. 1. Blank light emission curves obtained by injecting untreated $\left(A_{1}\right.$ to $\left.D_{1}\right)$ or apyrase plus $A M P$-deaminase-treated $\left(A_{2}\right.$ to $D_{2}$ ) crude firefly extract (Sigma FLE-50) into Tris-buffer. A: ATP-reagent; B: ADP-reagent; C: AMP-reagent; D: ADPreagent with 10 times higher pyruvate kinase concentration than in $\mathrm{B}(100 \text { and } 10 \mu \mathrm{l} \mathrm{PK} \mathrm{ml})^{-1}$, respectively)

(Romano and Daumas, 1981). This method is therefore demanding in terms of standardization (Christensen and Devol, 1980).

Alternative procedures for reducing the interference have involved dilution of incubated samples prior to assay (Witzel, 1979) or inactivation of AK and PK by treatment with perchloric acid (PCA) (Kimmich et al., 1975). Dilution represents loss of sensitivity, which can 
be disadvantageous with environmental samples of low AN content. PCA-treatment requires neutralization prior to assay. This is time-consuming, and loss of ATP through coprecipitation can be a serious problem (Kimmich et al., 1975).

Instead of eliminating the $\mathrm{PK}$ and $\mathrm{AK}$ activities of incubated samples, we developed a procedure aimed at reducing the content of interfering $\mathrm{AN}$ in crude firefly extracts. Aging is a common practice for lowering the blank light emission, and aging for $48 \mathrm{~h}$ reduced the ATP concentration of our FLE preparation from $0.15 \mu \mathrm{M}$ to less than $2 \mathrm{nM}$. The concentrations of ADP and AMP, on the other hand, remained at approximately 0.5 and $15 \mu \mathrm{M}$, respectively. Apyrase has been successfully applied to further reduce the background in assays of ATP based on peak light emission (e.g. Wettermark et al., 1975). In contrast, Kimmich et al. (1975) who used integrated light emission, did not obtain much reduction of their background through apyrase-treatment, presumably due to ATP production from AMP in the FLE preparation.

By treating the FLE with apyrase and AMP-deaminase, we were able to lower the AMP content of our FLE preparation almost 100-fold (Table 2). Blank light emission curves obtained with treated and untreated

Table 2. Effects of apyrase and AMP-deaminase on contents of adenine nucleotides in crude firefly extract (Sigma FLE50). One vial of FLE-50 was rehydrated with $25 \mathrm{ml}$ distilled water and aged for $20 \mathrm{~h}$ prior to the enzymatic treatment

\begin{tabular}{|lcll|}
\hline Treatment & $\begin{array}{c}\text { ATP } \\
(\mu \mathrm{M})\end{array}$ & $\begin{array}{l}\text { ADP } \\
(\mu \mathrm{M})\end{array}$ & $\begin{array}{l}\text { AMP } \\
(\mu \mathrm{M})\end{array}$ \\
\hline $\begin{array}{l}\text { None } \\
\text { Apyrase }+\end{array}$ & $<0.002$ & 0.02 & 3.78 \\
AMP-deaminase & $<0.002$ & 0.01 & 0.059 \\
\hline
\end{tabular}

FLE differed markedly. In contrast to the situation with untreated FLE, the peaks obtained with treated FLE were similar for all 3 reagents (Fig. 1). The PK concentration had a marked influence on the light emission following the initial peak, even with treated FLE. The PK concentration should therefore be kept low in order to reduce this interference, especially when untreated FLE is used. We found complete conversion of ADP $(20 \mathrm{nM}$ to $2 \mu \mathrm{M})$ to ATP in 20 min at $2^{\circ} \mathrm{C}$ with 8 units of $\mathrm{PK} \mathrm{m} \mathrm{ml}^{-1}$. Since incubations are usually carried out at $30^{\circ} \mathrm{C}$, this PK concentration (same as that used in Fig. 1B) is therefore more than sufficient.

Standard curves obtained with treated FLE and ATP standards in the range 6 to $100 \mathrm{nM}$ were linear $\left(r^{2}=0.992,0.998\right.$, and 0.988 for ATP-, ADP-, and AMPreagent, respectively). Apart from differences due to the ADP and AMP contamination of the ATP standard, the 3 standard curves were similar. The modified methodology as described here is therefore simple in terms of standardization requirements, and could form the basis for a routine, standardized assay procedure for $\mathrm{EC}$ determinations in marine ecological studies.

Acknowledgement. J. Klinken held a fellowship from the Nordic Council for Marine Biology during this study.

\section{LITERATURE CITED}

Aledort, L. M., Weed, R. I., Troup, S. B. (1966). Ionic effects on firefly bioluminescence assay of red blood cell ATP. Analyt. Biochem. 17: 268-277

Atkinson, D. E. (1977). Cellular energy metabolism and its regulation. Academic Press, New York

Beutler, E., Mathai, C. K. (1967). A comparison of normal red cell ATP levels as measured by the firefly system and the hexokinase system. Blood 30: 311-320

Chapman, A. G., Fall, L., Atkinson, D. E. (1971). Adenylate energy charge in Escherichia coli during growth and starvation. J. Bact. 108: 1072-1086

Christensen, J. P., Devol, A. H. (1980). Adenosine triphosphate and adenylate energy charge in marine sediments. Mar. Biol. 56: 175-182

Green, A. A., McElroy, W. D. (1956). Crystalline firefly luciferase. Biochim. biophys. Acta 20: 170-176

Haya, K., Waiwood, B. A. (in press). Adenylate energy charge and ATPase activity: potential biochemical indicators of sublethal effects caused by pollutants in aquatic animals. In: Nriagu, J. O. (ed.) Aquatic toxicology. John Wiley, Chichester

Holmsen, H., Holmsen, I., Bernhardsen, A. (1966). Microdetermination of adenosine diphosphate and adenosine triphosphate in plasma with the firefly luciferase system. Analyt. Biochem. 17: 456473

Holmsen, H., Storm, E., Day, H. J. (1972). Determination of ATP and ADP in blood platelets: a modification of the firefly luciferase assay for plasma. Analyt. Biochem. 46: 489-501

Ivanovici, A. M. (1980). Adenylate energy charge: an evaluation of applicability to assessment of pollution effects and directions for future research. Rapp. P.-v. Réun. Cons. perm. int. Explor. Mer 179: 23-28

Karl, D. M. (1980). Cellular nucleotide measurements and applications in microbial ecology. Microbiol. Rev. 44: 739-796

Karl, D. M., Holm-Hansen, O. (1978). Methodology and measurement of adenylate energy charge ratios in environmental samples. Mar. Biol. 48: 185-197

Karl. D. M., LaRock, P. A. (1975). Adenosine triphosphate measurements in soil and marine sediments. J. Fish. Res. Bd Can. 32: 599-607

Kayne, F. J. (1973). Pyruvate kinase. In: Boyer, P. D. (ed.) The enzymes, Vol. 8. Academic Press, New York, p. 353-382

Kimmich, G. A., Randles, J., Brand, J. S. (1975). Assay of picomole amounts of ATP, ADP, and AMP using the luciferase enzyme system. Analyt. Biochem. 69: 187-206

Lundin, A., Thore, A. (1975). Comparison of methods for extraction of bacterial adenine nucleotides determined by firefly assay, Appl. Microbiol. 30: 713-721

Noda, L. (1973). Adenylate kinase. In: Boyer, P. D. (ed.) The enzymes, Vol. 8. Academic Press, New York, p. 279-305

Pradet, A. (1967). Étude des adénosine-5'-mono, di et triphos- 
phates dans les tissus végétaux. I. Dosage enzymatique. Physiologie vég. 5: 209-221

Romano, J.-C., Daumas, R. (1981). Adenosine nucleotide 'energy charge' ratios as an ecophysiological index for microplankton communities. Mar. Biol. 62: 281-296

Skjoldal, H. R. (1981). ATP concentration and adenylate energy charge of tropical zooplankton from waters inside the Great Barrier Reef. Mar. Biol. 62: 119-123

Skjoldal, H. R., Barkati, S. (1982). ATP content and adenylate enery charge of the mussel Mytilus edulis during the annual reproductive cycle in Lindåspollene, western Norway. Mar. Biol. 70: 1-6

Van Dyke, K., Stitzel, R., McClellan, T., Szustkiewicz, C.
(1969). An automated procedure for the sensitive and specific determination of ATP. Clin. Chem. 15: 3-14

Wettermark, G., Stymne, H., Brolin, S. E., Petersson, B. (1975). Substrate analyses in single cells. I. Determination of ATP. Analyt. Biochem. 63: 293-307

Wiebe, W. J., Bancroft, K. (1975). Use of the adenylate energy charge ratio to measure growth state of natural microbial communities. Proc. natn. Acad. Sci. USA 72: 2112-2115

Witzel, K.-P. (1979). The adenylate energy charge as a measure of microbial activites in aquatic habitats. Arch. Hydrobiol., Beih., Ergeb. Limnol. 12: 146-165

Accepted for printing on May 16, 1983 